Article

\title{
Beyond Atheism and Atheology: The Divine Humanism of Emmanuel Levinas
}

\author{
Manuel A. Cruz \\ College of Theology \& Christian Ministry, Belmont University, 1900 Belmont Blvd., Nashville, TN 37212, USA; \\ manuel.cruz@belmont.edu
}

Received: 2 January 2019; Accepted: 15 February 2019; Published: 23 February 2019

check for updates

\begin{abstract}
Is the divine a meaningful and indispensable element of moral responsibility? Emmanuel Levinas' ethics have brought new expression to the question of God and the Good. Contemporary engagements with Levinas' provocation, however, have generated a morass of contrary judgments and enigmatic explications, including praise and criticism for its atheology, secular transcendence, and crypto-religious conceit. The essay takes issue with secular and atheistic interpretations of Levinas, arguing that his mature ethics offer a philosophical species of divine humanism, one that justifies the indispensable significance of the divine for moral responsibility. It examines the philosophical problems that lead to the creation of new phenomenological descriptions for divine transcendence, and it sheds light on the seemingly erratic scattering of divine names-infinite, third person, trace, immemorial past, absence, beyond being, illeity—as improvisational orchestrations for God at the margins of moral responsibility.
\end{abstract}

Keywords: humanism; ethics; God; being; Heidegger; Levinas; absence; phenomenology; atheism; transcendence

\section{Beyond Atheism and Atheology}

The ethics of Emmanuel Levinas contains some of the most innovative and perplexing deployments of religious language, divine names, and biblical references within contemporary philosophy. Alongside Paul Ricoeur, Levinas stands at the forefront of decades of contested yet fertile cross-pollination across the disciplines of philosophy, theology, and religious studies. ${ }^{1}$ Whether by way of philosophical appropriations of transcendence-the Infinite, Absolute, Beyond Being, or the One-or the biblical language of prophecy, witness, and glory, Levinas weaves into the heart of his philosophical endeavors language that reverberates with religious significance.

Despite the fecundity of his work for Continental thinkers, and notwithstanding his ostensibly favorable disposition toward religious ideas and his native Judaism, Levinas' philosophical appropriation of religion continues to spark passionate disagreement and suspicion from religious and secular quarters alike. One need only consider the slew of contrary and enigmatic epithets that his thought has engendered: theological hostage-taking (Janicaud 2000), a gift for theology (Zimmerman 2013), atheological (Llewelyn 1995), atheistic theology (Franks 2010), atheism (Westphal 2010), post-modern apologetics (Gschwandtner 2012), philosophy of religion (Kosky 2001), and secular transcendence (Maloney 2014). ${ }^{2}$ Levinas' appropriation of religious language into philosophy has been regarded as dangerous and harmful to the disciplinary integrity of both philosophy and theology. Paul Franks

1 One need only consider the work of Jacques Derrida, Maurice Blanchot, Jean-Luc Marion, Jean-Luc Nancy, Mark Taylor, John Caputo, et al., whose works and engagements have given rise to the discursive constellation of Continental philosophy of religion.

2 Detailed references and page numbers for the article are available from the author upon email request. 
has thoughtfully framed the problem and concern thus: Is the philosophical appropriation of biblical ideas and language a philosophical Trojan Horse-a seductive yet ruinous gift for Jews and Christians (Franks 2010)? Dominic Janicaud's foray into the question, The Theological Turn in French Phenomenology, has provoked the complementary suspicion that the philosophical appropriation of religious ideas in Levinas and other influential Continental thinkers represents a theological agenda that corrupts the methodological integrity of phenomenology and philosophical inquiry (Janicaud 2000; Simmons 2010). The current essay is an attempt to surpass this morass of suspicions, contrary judgments, and dismissals, and to do so by clarifying and defending the philosophical appropriation of the divine in Levinas' ethics.

\section{Ethics and God: Disentangling the Gordian Knot}

Is God a meaningful and indispensable element of ethical responsibility? While secular sensibilities bristle at the suggestion that God would serve as the origin of moral obligations, the ethics of Emmanuel Levinas present a robust yet enigmatic argument for the indispensable trace of the divine at the margins of inter-personal responsibility. Levinas insinuates the meaning and eventuality of God into the subjective structures of responsibility for one's neighbor. Yet, the ties that bind ethics to God have been shown to form a Gordian knot that provokes and vexes the intellectual and practical aspirations of religious and secular interests. On the one hand, Levinas never ceases to denounce theology-rational and fideistic-in its attempts to represent and prove the essence, being, and existence of God (Levinas [1961] 1969; Levinas 1998; Levinas [1993] 2000). In fact, living without God—atheism—is an integral and significant achievement on the path to selfhood and genuine moral encounter with another (Levinas [1961] 1969). At the same time, the ubiquitous deployment of the Cartesian name for God-the Infinite- and the radical transcendence this name confers upon the human being inflect Levinas' ethics with an enigmatic and indispensable relation to the idea of God, if not the divine itself (Levinas [1961] 1969). This enigmatic insinuation of God into moral life-God and the Good as interwoven threads of a singular life-is best discerned and disentangled beginning with the essays that connect Levinas' two great philosophical works.

On the heels of the formidable Totality and Infinity, Levinas commences an extraordinary reformulation of the language and analyses that describe the moral significance of transcendence. The consummate expression of this extensive revision is unveiled thirteen years later in Otherwise than Being or Beyond Essence, and it remains the principal conceptual lexicon for the rest of Levinas' works. During these intervening years, Levinas develops an ensemble of diverse ways to name and give meaning to the divine. These ideas give shape to a new direction in Levinas' thinking concerning the meaning of God and the role that God plays in the signification of transcendence and the moral life.

Tracing the development of Levinas' thinking from Totality and Infinity to Otherwise than Being, it becomes clear that the idea of the Infinite is refashioned into the personal yet absent origin of ethical responsibility, such that Levinas' ethics present nothing short of a divine humanism: the divine inflection of human responsibility. To reach this extraordinary thesis-the divine as the absent and personal origin of human responsibility—Levinas and his readers must contend with three problems:

1. The first concerns meaningful language for the divine and the elusive status of the divine vis à vis the human other. How does one name the divine, and what precisely do these names signify-an idea, being, event? Do these names refer to something other than the human other?

2. The second centers on the relationship between responsibility and the divine. What role does the divine play in the constitution of human responsibility? What philosophical problems lead to the inclusion of the divine within the fold of ethical responsibility?

3. The final problem: Is the relation to divinity an indispensable element of human responsibility? 


\section{Naming the Divine: Improvisations in Philosophical Jazz}

As early as 1963, a new constellation of phenomenological descriptions begins to appear in Levinas' writings: illeity, immemorial past, otherwise than being, absence, and trace (Levinas [1967] 1986). Each of these descriptions develops a distinct facet of divine signification, that is, the way that meaning is given to the divine. The proliferation of these divine names coincides with a significant shift in the meaning and function of the two-fold cast of persons-the I and the Other-which in Totality and Infinity engender the idea of the Infinite in everyday life.

In Totality and Infinity, the idea of the Infinite enters the life and mind of the I through its concrete moral encounter with the transcendent face of the Other-the living moral expression of the human before me. In this encounter, the face of the Other (Autrui) presents itself as infinite and absolutely other (autre) (Levinas [1961] 1969). The infinity and otherness of the face signify the transcendence that is proper to this human other. "The absolutely other is the Other" (Levinas [1961] 1969). The Other is not God in any conventional or traditional sense of the word. It is the human other "expressing" and "revealing" infinite transcendence (Levinas [1961] 1969). Whereas for Descartes the 'infinite' named the transcendence proper to God (Descartes 1984), for Levinas it is a way to name the transcendence proper to the humans I encounter in everyday life. The human before me presents itself infinite, transcendent, and wholly other, hence its quasi-divine designation as lord, master, and Other.

In the face of the Other, one is confronted with a dialectical oscillation between the revelation of its infinite transcendence and its finitude: "This gaze that supplicates and demands, that can supplicate only because it demands, deprived of everything because entitled to everything ... To recognize the Other is to recognize a hunger. To recognize the Other is to give. But it is to give to the master, to the lord, to him whom one approaches as "You" in a dimension of height" (Levinas [1961] 1969). Let us note the paradox: recognizing the other as vulnerable and deprived, as finite, depends on first recognizing the eminence and excess of its lordship as the infinite. The ethical significance of finitude depends on the prior significance of the infinite. There is a provocative intimation that the person I encounter on the street—subject to hunger, poverty, and murder-arrays itself with all the transcendent stature of a god, in essence signifying this vulnerable human in some way divine.

The primacy of the divinity of the human certainly runs counter to secular efforts to purge contemporary thought and society of religious ideas, language, and traditions, not least the idea of the human as the image of God. The notion that the human other reveals itself as the Infinite, as the wholly Other, evokes and warrants understandable suspicion of a crypto-religious agenda. Yet, the infinity of the human Other is not a consequence of God's creation, loving-kindness, or grace. There is no mention of an actual God, who functions as the agent or cause of this human divinization. Furthermore, divinization does not follow from human participation in the life of God, nor any conventional form of divine invocation or prayer. Rather, the infinite heights and lordship of the human Other are revealed in the generosity, truth, universality, and peace of spoken discourse arising from human beings in direct contact with one another: I and the Other. The two-fold cast of one human speaking to another is all that is required to disclose the infinite transcendence of the human moral life (Levinas [1961] 1969). While the idea of God plays a significant role in Levinas' description of the encounter, God qua person or being does not play a vital or necessary role in the inter-human signification of the infinite, at least not yet.

In the works that follow Totality and Infinity, Levinas goes out of his way to introduce a third person into the ethical cast of transcendence. At the margins of the ego's extraordinary encounter with the transcendent face of the human other, there arises the passing trace of a new and distinct personal relation: "the beyond from which the face comes is the third person" (Levinas [1967] 1986). Who is this third person, and what is this new relation? Does it alter the two-fold relation that holds between me and the human other? Is the third figure simply another human other, obliquely signified as 'that one there', the one whose face is not directly before me? Or, if it is some kind of divine person, by what name and avenue of access does the divine enter the circuit of human consciousness? 
Levinas' descriptions of the third person are intricate, resembling the subtle and complex dynamics of improvisational jazz. The irreducible variations, unanticipated deployments, and novel modulations of the third person should be approached as improvisational moments in an arrangement of philosophical jazz. The third person goes by an irreducible variety of names-illeity, beyond being, Infinite, ' $\mathrm{He}^{\prime}$, even God-terms which remain permanent fixtures of Levinas' writings. Rather than deny the possibility of naming the divine, as some have suggested (Gschwandtner 2012), Levinas floods the reader with a perichoretic ensemble of names, a plurality of names dancing around and across one another. There is no singular way to name the third person. Moreover, there is always an unanticipated novelty and nuance to the perpetually shifting arrangement of names that describe the relation, as Levinas artfully weaves the third person in and out of different aspects of his thought. While a recognizable pattern of descriptions does emerge, it is neither linear nor systematic in its articulation. The unforeseeable deployment and irreducible plurality of the divine names resist the universal identity of concepts and the formal prescriptions of logical or systematic order. The ever-shifting ensemble of divine names simply cannot be pinned down, so as to identify one universal divine essence. Despite his improvisational resistance to systematic and conceptual discourse, there are prominent names and recurring themes that emerge, most notably 'illeity'.

Illeity signifies a relation to a third person at work in the unfolding of absolute responsibility. It is a clunky neologism that Levinas fashions from the Latin third person singular masculine pronoun ille and its French equivalent $i l$, he (Levinas [1974] 1998). As an indexical, the referential meaning of ille depends on contextual specification, whether by way of person he, location that one yonder, or time the prior one. Levinas takes advantage of this semantic plasticity, such that illeity can signify a personal relation to a third person 'he', a temporal relation to that which is 'past', or a reference to location 'beyond' or 'absent'. The variable meaning and use of illeity becomes clear, as one discerns which contexts-temporal, personal, or spatial-are at work in a given passage. As with the divine names, the various deployments of illeity follow an improvisational jazz-like pattern of fluidity, alternation, and plurality against the rhythmic repetition of the "absolute".

Across these variations, Levinas often privileges the personal, though spatial and temporal references to the absolute are often folded into the personal. Illeity signifies a relation to the "absolute $\mathrm{He}^{\prime}$. (Levinas 2001). "Il", "He" signifies someone in the third person, that is, an absolute person who relates to me (the first person) and to you (the second person or other) from over yonder, not here, or as Levinas prefers, from beyond, absent. This "beyond" coincides with the spatial, or rather contra-spatial, significance of ille, which Levinas ultimately associates with utopia, etymologically signifying one who does not have a place, and thus one who cannot be enshrined in a church or ensconced in the world (Levinas [1991] 1998). Let us consider the following ensemble of the personal, the absolute, and the temporal: "The pronoun He ... expresses ... [the] absolutely unencompassable or absolute, a transcendence in the ab-solute past. The illeity of the third person ... " (Levinas [1967] 1986). The temporal significance of ille is here indicated by way of the "ab-solute past", which reinforces the temporal detachment of this third person from the persons and world to which it relates.

Across the linguistic and conceptual intricacies of illeity, one discerns a traditional echo of the divine. "He" is absolute, before all things, and yet belongs to a time that has passed beyond hope of recovery or remembrance. While the first element resonates with traditional monotheistic sensibilities, including its gendered masculinity, the second intimates the irrecoverable passing of God from contemporary life and consciousness, as though secular society has progressed beyond its primitive need for gods or finds itself lost in nihilistic despair over the silence of the heavens.

When one considers the descriptions of illeity as 'unencompassable', 'absolute', 'transcendence', and even the enigmatically hyphenated 'ab-solute', it is striking that this third person is described in precisely the same terms ascribed to the human Other in Totality and Infinity (Levinas [1961] 1969). It is certainly possible that illeity simply offers another way to signify the human other in its transcendence, as Levinas does not shy away from multi-faceted descriptions of the same phenomenon. Yet, identifying illeity with the human other fails to explain why transcendence is now framed in 
the third person, as belonging to someone that is not present before me, but rather belongs to the past in some absolute sense. The association of illeity with the absolute past plays on the temporal significance of ille as 'the prior one', the one whose priority belongs to an absolute or irrecoverable past. For now, it is sufficient to recognize how "that one, the absolute" is never present, and thus cannot engage in a concrete encounter face to face, the latter of which constitutes the essence of my relation to the other (Levinas [1961] 1969). Without standing in the present moment, it becomes impossible to encounter this transcendent third person in the here and now of present realities, phenomena, and everyday life. This leads to the ascription of profound absence. Unlike the neighboring Other, the third person is absent. Anticipating the potential for mistakenly identifying the third person with the rest of humanity_-"the third party" (le tiers) —Levinas writes: "the Infinite escapes the objectification of thematization and of dialogue, and signifies as illeity, in the third person. This 'thirdness' is different from that of the third man ... with which justice begins" (Levinas [1974] 1998). Thus, the third person must be regarded as someone new and distinct, who exhibits the similar qualities of absolute and uncontainable transcendence as the human face, yet cannot be encountered in everyday life.

Illeity names the detachment of the Infinite in the midst of the relation it establishes between the I and the Other (Levinas [1993] 2000). The third person has a relation to the I and to the face of the human Other, but the relation is one of radical detachment with respect to speech and comprehension. "The Infinite escapes the objectification ... of dialogue, and signifies as illeity" (Levinas [1974] 1998). Illeity speaks to the way that the Infinite does not speak to the self and the other; it does not enter into face-to-face dialogue. "The detachment of the Infinite from the thought that seeks to thematize it and the language that tries to hold it in the said is what we have called illeity" (Levinas [1974] 1998). Illeity also describes how the intellect cannot limit the meaning and signification of the Infinite to the measure of its conceptual apprehension. The fact that the Infinite 1) cannot be limited to conceptual knowledge, and 2) does not appear, speak, or otherwise directly engage with the self and other, does not however mean that the Infinite is inaccessible to thought. "It preserves its illeity to the point of letting it be excluded from the analysis, save for the trace it leaves in words or the "objective reality" in thoughts, according to the unimpeachable witness of Descartes' Third Meditation" (Levinas [1974] 1998). In short, there are traces of this Infinite third person in our thoughts and language.

It is worth noting that the detachment of the I and the Other is already a central thesis of Totality and Infinity (Levinas [1961] 1969). In its infinite expression, the Other secures its irreducible detachment from the I, overcoming the egoism that sought to incorporate or dissolve all otherness into the life and being of the I. With the introduction of illeity, there is however a significant shift in the contours of this inter-personal detachment. The Infinite emerges as someone that is distinct and detached from the Other, thus establishing the Infinite as a third transcendent person, 'that one', who has passed by my relation to the human Other. It is no longer the Other who initiates and operates its detachment from the I. Detached from its former infinity, the Other is no longer able to defeat the robust egoism of the I on its own. The Other now depends on another, the infinite third person, for its irreducible detachment from the egoistic ventures of the I.

Who then is this infinite third person? "God is ... the third person or Illeity" (Levinas [1993] 2000). Levinas repeats this stunning identification of the infinite, God, and illeity on multiple occasions. "And this way for the Infinite, or for God, to refer at the core of its own desirability ... to the undesirable proximity of others we have designated by the term 'illeity'" (Levinas [1998] 1996). Infinite transcendence is no longer the two-fold drama of the I and the infinite human other. Now, the infinity of my responsibility for the other is henceforth reconceived across a three-fold constellation of personal relations- the I, the human other, and the Infinite qua God. As the Infinite, God emerges as a detached third person in the transcendent unfolding of moral responsibility.

What then is the philosophical role of this detached, absent, and divine third person? The third person, which on rare occasion Levinas names 'God', plays an essential role in the attempt to displace Being as the original and fundamental horizon of meaning, appearance, and reality. While Levinas' critique of Being and ontology stretches back into his pre-war writings, it comes into its 
consummate expression over three decades later with the aptly named Otherwise than Being, or Beyond Essence. Levinas there appears to concede that the conceptual and phenomenal horizon of Being is a far more robust and permanent dimension of appearance and meaning than he had previously acknowledged. ${ }^{3}$ Any venture beyond being must pass through being or one of its many surrogates-conceptual representation, apophansis, empirical visibility, or knowledge. Transcendent passage through being must nevertheless have the extraordinary capacity to disrupt and reverse the ontological and conceptual structures of appearance and manifestation (Levinas [1974] 1998). As in Totality and Infinity, inter-personal ethics provides the ontologically disruptive path for transcendence. One's moral responsibility for the other- "the one for the other"-brings about the phenomenal disruption required for one to give life and meaning in a way that differs from being and signifies beyond being. In sum, one's responsibility for the other signifies "beyond being".

It is certainly possible to understand "beyond being" as a negative description of human responsibility, namely that responsibility does not participate in being. It is also possible to conceive of "beyond being" as signifying a transcendent domain of ethical meaning and eventuality, which one could abstractly name the ethical or the infinite. Levinas' essays, however, make it clear that "beyond being" signifies more than what responsibility is not, and that it signifies more than the abstract or formal horizon of the infinite or the ethical. Beyond being ultimately signifies the third person. "The personal order which compels us to the face, is beyond Being. Beyond Being is a third person, which is not defined by the Oneself, by ipseity ... The beyond from which the face comes is the third person" (Levinas [1967] 1986). 'Beyond Being' is thus one more way to name the third person at work in the unfolding of moral transcendence. It expands the ever-growing repertoire of names for this divine and personal third: illeity, ' $\mathrm{He}^{\prime}$, the Infinite, God, and now Beyond Being. Even more striking is the role of this Beyond Being within one's moral encounter with the face of the other. It is the Beyond Being, who compels me to responsibility for the other. Likewise, the face I encounter, that of the Other, comes to me from the Beyond Being. Thus, it is the Beyond Being who deploys the relation of responsibility upon the I and the Other, even as it detaches itself from it. Given the improvisational interchange of 'Beyond Being' with 'God' and other divine names, the Beyond Being insinuates the name and person of the divine into the philosophical centerpiece of Levinas' mature writings and into the very title of Otherwise than Being or Beyond Essence.

The introduction of the divine as the Infinite and Absolute third person leads to a startling yet equivocal demotion of the once transcendent Other. The face-to-face encounter with the Other is no longer regarded as an immediate or direct encounter with the Infinite or Absolute. Instead, Levinas increasingly uses the language of "neighbor" to name the human Other. The Other I encounter is my neighbor, who I address in the second person as 'you'. In Enigma and Phenomenon (1965), Levinas writes: "Desire ... or morality is a scheme of three: the I approaches the Infinite by going generously toward the You" (Levinas 2001). The second person, You, is "my neighbor who watches me" and "a face" for whose sake I forget myself in generosity and sacrifice. The Other becomes 'You', the one who faces me, which I recognize as my neighbor. In the context of Totality and Infinity, the face of the Other had presented itself as infinite and absolute. In direct reversal of his former thesis, Levinas now claims that "it is ... vain to posit an absolute You" (Levinas 2001). The face of the other, my neighbor, no longer rises to the level of the absolute, at least not on its own. "The face can appear as face ... only if it comes enigmatically from the Infinite and its immemorial past" (Levinas 2001). In other words, I can give myself to You, my neighbor, only if you come to me from another, the Infinite. The Infinite is henceforth presented as though it were other than the Other. The Infinite, the absolutely other, is no longer Autrui, the other human. The one who faces me is no longer the Infinite. This was the dramatis personae Levinas set forth in Totality and Infinity. The Infinite is now "the absolute He" - the divine

3 In Totality and Infinity, erotic love, egoistic hedonism, and the divinized face of the other offered different ways for thought, individuals, and the rhythms of life to break free of the inherently violent and impersonal horizon of being and conceptual representation. 
person (Levinas 2001). Levinas has come to recognize that the rank of absolute cannot be given to one's neighbor, the other who dwells with me and before me.

Much of communal life, whether it is examined through the natural attitude or an existential phenomenal attitude, is spent with others as neighbors, simply content to let them be, that is, to let them be finite. Existing alongside my neighbor (being-with as Heidegger would say) in our respective finitude is a common and manifest way for me to live and encounter others, even if it is not a meaningful and transcendent way to live.

Yet, underlying the peaceful indifference of being with one's neighbors, there ceaselessly irrupts a provocation to sacrifice oneself for one's neighbor. Empirically, the sacrifice may be a simple gesture of acknowledgement, the implementation of a policy, or the loss of oneself for one's children. Whatever its ontic or empirical actuality, the phenomenal horizon of being is pierced and with it peaceful indifference toward one's neighbor is removed. The significance of the neighbor in itself remains finite, but it is a finitude approached through the infinity of one's responsibility. This sense of infinite

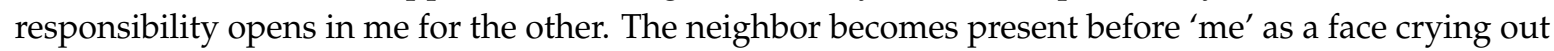
for infinite generosity and responsibility. The neighbor, the other, is no longer someone Infinite and Absolute; he no longer commands as an infinite lord and master.

My neighbor remains finite, even as the immeasurable inflection of my responsibility opens from the third person, 'that one', who takes up the divine name and mantle of the Infinite and the Absolute. This is a profound change in Levinas' thinking. First, the meaningful signification of ethical transcendence-infinite responsibility—now requires a three person cast: 'me', 'you', and 'the Infinite'. Second, the transcendent mantle of the infinite shifts away from the unique human being before me to a divine person, who will remain profoundly absent, a shadowy figure at the margins of infinite responsibility. Third, stripped of the dialectical oscillation of lord and beggar, the infinitely responsible subject can approach the other in her finitude without transcendent fear or confusion, that is, simply in their need and vulnerability to suffering, violence, and death. What remains to be seen are the philosophical reasons for this significant shift: what philosophical problems animate the introduction of the divine as a third person within the moral scene of transcendence?

\section{Overcoming Onto-Theo-Logy: A Philosophical Insurgency}

As with any robust philosophical development, Levinas' decision to introduce the divine into the core of ethical life can be traced back to a question. While Levinas' philosophical inquiry may draw on Jewish ideas and sensibilities in significant ways, he "empties it of its theological connotations or its context of faith and instead employs it for purely philosophical ends" (Gschwandtner 2012). It is thus not a question of faith or religious commitments, but rather one of ethics, philosophical ethics, and even more so one of phenomenology. The question: What phenomena can attest to the transcendence of persons beyond being-the self, the other, and society? The context at play is nothing short of Levinas' philosophical insurgency against Martin Heidegger's life-long endeavor to recover the meaningful disclosure of Being from its concealment in Western metaphysics.

One dimension of Heidegger's vast salvage operation, which has received significant attention from Continental philosophers, is his attempt to overcome theological metaphysics-what he called the "onto-theo-logical constitution of metaphysics" (Westphal 2001). The philosophical tradition of theological metaphysics may be traced to back to Aristotle's Metaphysics and weaves across various forms of late Medieval and Modern metaphysics, including those of Suarez, Descartes, Leibniz, Kant, and Hegel. ${ }^{4}$ As Heidegger defines it, onto-theo-logy refers to metaphysical projects that enlist the idea of a highest being "God" as the cause, justification, or exemplar of the common essence of

4 What specific philosophers and projects best fit the metaphysical framework of onto-theo-logy has been an important line of research among Continental philosophers. The philosophers mentioned here should be regarded as a list of 'usual suspects'. The question of whether and how they may be complicit in the "onto-theo-logical constitution of metaphysics" extends well beyond the current scope. 
beings (Heidegger 1969). In deceitfully simple terms, the being of God functions as the ground of all being. By identifying the essence and rationality of being with the actuality of a highest being, onto-theo-logy works to establish an enclosed totality of rational being, on the basis of the fundamental identity of being. For Heidegger, this ontological identity conceals the original difference of being-the being of beings-which opens (rather than encloses) a horizon of possibilities for the manifestation of beings. The ontological difference serves as the essential origin of the meaningful disclosure of being. By separating the disclosure of being from its rational and causal relation to God, the overcoming of onto-theo-logy opens one of many possible paths back into the ontological difference (Heidegger 1969). While Heidegger leaves open the possibility of rethinking God from within the newly liberated difference, his primary interest always remained the recovery of the being of beings.

As early as 1940, twenty years before the writing of Totality and Infinity, Levinas launches a philosophical insurgency against Heidegger's holy grail: the phenomenological primacy of the being of beings (Taminiaux 1997). Levinas' opposition to Heidegger is no facile rejection, as he himself helped conduct Husserlian and Heideggerian phenomenology into the French philosophical scene, and continued to draw from its wells for decades to come. Yet, it becomes increasingly clear to Levinas that the disclosure of being threatens to erode the personal dimensions of the individual subject. The way forward calls for more than ontological differentiation; it calls for "separation" from being (Levinas 1987). Levinas increasingly advocates the phenomenological separation of persons from the anonymity of the ontological difference and from the impersonal violence of the rational totality of being, which the idea of God as absolute ground of being made possible. Both forms of being-the ontological difference and onto-theo-logy—threaten the unique and irreplaceable constitution of the I, the other, and the plurality of others who make up society (Levinas [1961] 1969).

Levinas' earliest explorations of the personal dimensions of consciousness and subjectivity consist of phenomenological descriptions of the I (the first person) in its embodiment, temporality, materiality, toil, solitude, insomnia, and encounter with the feminine other. In these descriptions, Levinas is ever mindful of the impersonal threat of being (Levinas 1987). By Totality and Infinity, Levinas has settled on the Cartesian idea of God qua Infinite as the formal avenue for securing the unique and inviolable significance of the I and the Other. Though arguably part of the onto-theo-logical tradition, Levinas holds that the idea of the Infinite signifies an untapped excess, which would liberate it from its ontological significance, if it were phenomenologically deformalized in the concrete encounter with the face of the Other (Levinas [1961] 1969). The argument consists of a formal and a concrete thesis:

1. Formal: When the idea of God as Infinite is liberated from its ontological significance within theistic metaphysics, one retains the formal idea of transcendence (beyond being).

Phenomenological analysis demands that one shift to lived experience and inquire (i) whether there is a phenomena or other lived experience across which consciousness encounters this formal idea, and (ii) how the concrete phenomena deformalizes or gives flesh, as it were, to the idea.

2. Concrete: In my encounter with another, I experience this other expressing itself as an infinite and transcendent moral authority over me, inviting and demanding that I respond to her beyond the rational totality of being.

3. Outcome: The I and the Other engage one another (asymmetrically) as unique and personal beings, thereby overcoming the (onto-theo-logical) threat of the totality of being.

Despite the rigor and innovation of Totality and Infinity, Levinas almost immediately begins anew, once more taking up the insurgent task of overcoming the phenomenal manifestation of being with new phenomenological descriptions and structures. His decision to renew his efforts to overcome being raises the question as to what philosophical work remains to be done. It seems clear that Totality and Infinity significantly, if not effectively, addressed the threats to self and other posed by an enclosed totality of being. Moreover, it showed how a phenomenological deconstruction of the metaphysical idea of God as Infinite could establish the transcendence of persons-self and other-beyond the ontological violence of totality. In this respect, Levinas' shortcoming is not that he replaced an onto-theo-logy with 
an ethico-theo-logy that repackaged the philosophical violence of the former regime (Kosky 2001). Furthermore, the view that the language and ideas of Totality and Infinity contained a contaminating ontological residue is not altogether convincing (Derrida 1978). Rather, what is left unaddressed is Levinas' earliest concerns over the primal anonymity of the being of beings, that is, the disclosure and manifestation of being in the ontological difference. Having addressed the onto-theo-logical threat of totality, Levinas now commences a second philosophical insurgency against the disclosure of being (Heidegger), and it is this threat that leads to the introduction of the divine as third person.

\section{Tearing the Fabric of Being}

Once more, the phenomenological question at play begins with the disruption of being, for it is being that seemingly constitutes the perpetual appearing of the world and everything in it. It is Levinas' contention that the face of my neighbor disrupts the finite and phenomenal horizon of being or existence. My neighbor somehow overturns the phenomenal primacy of the world and of being, which had served as the pervasive and comprehensive context in which all meaning and appearance take place. The disruption of this ontological and global context is what allows consciousness to apprehend an infinite and non-phenomenal call to responsibility for the neighbor. Yet, how is it possible for an encounter with one's neighbor to disrupt something as fundamental and ceaseless as the ontological appearance of the world before consciousness? "How is the neighbor ripped out of context?" (Levinas 2001). It is this phenomenological problem that ultimately leads Levinas to argue for the divine as an indispensable third person at the margins of the ethical encounter. Totality and Infinity advanced the view that the Other, the human other, was in itself sufficient to account for the phenomenal disruption of being and of the appearing of the world. The essays that follow clearly indicate that Levinas has called this earlier position into question and has now enlisted a divine person to explain the phenomenal and ontological iconoclasm of the face.

The Question: How is it possible for the neighbor to present itself as a face-beyond the phenomenal contours of experience, of being, and of the world? Answer: The possibility of the face can only be explained by way of a relation to the absolute and immemorial past of the Infinite (Levinas 2001). Yet, the Infinite does not ever enter into the temporal horizon of being, wherein one's recollection of past events might glimpse the divine. God dwells, as it were, in an immemorial past beyond any possibility of being or visibility. By coming to me from this divine absence of being, my neighbor is likewise ripped out of the phenomenality of being, which is not to say she is annihilated or reduced to non-being. Beyond the alternatives of being and non-being, the face of my neighbor-no longer a phenomenon but a cry for goodness-is presented as the trace left by the Infinite. The "invisible that bypasses the present left a trace by the very fact of bypassing the present. That trace lights up as the face of a neighbor, ... him before whom ... and him for whom I answer" (Levinas [1974] 1998). The trace is not evidence, but a path, a virtually indiscernible path, obscured twice over by the phenomenal visibility of being and the invisibility of the divine break with the visible. The only bearing that remains is the cry for goodness one hears before the neighbor. The trace-path that the Infinite has left for the conscious subject is one of sacrifice for the neighbor. Let us be clear: God is the one who has cleared the path that enables a person to give oneself away. "He solicits across a face, the term of my generosity and my sacrifice. A You is inserted between the I and the absolute $\mathrm{He}^{\prime \prime}$ (Levinas 2001). It is God who, in the face of the other, has cried out for my goodness, for my generosity and sacrifice for the other.

Once more, there is a significant reversal in Levinas' ethical scheme. It is no longer the human Other, who pleas, demands, and summons me to respond and to speak. Now, it is the divine who cries in the face of the Other. Is the Other silent? It may not matter as the human call for conversation and interpersonal discourse increasingly gives way to a divine call to substitute and sacrifice oneself for the other (Kosky 2001).

The reason that the trace can signify the absolute past, the reason it does not fall back into the order of manifestation, is that "the trace signifies beyond Being". "He" is supreme and absolute in its 
transcendence of Being, to the point that "He" does not ever enter into the purview of one's presence. God is "transcendent to the point of absence" (Levinas [1993] 2000; Levinas [1998] 1996). But what is meant here by presence and absence? Here, one must consider how consciousness is understood within Levinas' phenomenology.

Presence is the first fruit of a conscious return to oneself. Consciousness gathers the ever-flowing and dispersed array of events, images, and affections that one undergoes and sets them within the finite and principled frame of presence before a subject. By way of this finite frame or principle (arche), two events take place in direct correlation to one another. The subject of consciousness recovers its identity; it returns to itself (soi-même). And by the same return, events are converted into beings and objects, whose presence appears before consciousness (Levinas [1974] 1998).

The face disrupts this two-fold conversion of events into presence and of otherness into oneself. It is Levinas' mature contention that the face on its own can neither initiate nor sustain such a profound destabilization of the reflexive activity of consciousness. To effectively disrupt the conscious production of presence, consciousness must enter into relation with something, or rather someone, so utterly transcendent that it cannot be reduced into a presence, and thus remains absent. Such a thing is "God ... transcendent to the point of absence" (Levinas [1993] 2000).

The radical absence of God becomes the transcendent condition for the disruptive, irreversible, and recurrent redirection of the self to the other, and of being into responsibility. "The illeity of the third person is the condition for the irreversibility" (Levinas [1967] 1986). The divine third prevents the coming of the face from turning back into a worldly manifestation of the other. "This detour at a face and this detour from this detour in the enigma of a trace we have called illeity" (Levinas [1974] 1998). I am redirected to the face and redirected to the trace, insofar as I do not return to myself. The detour to my neighbor, the detour on which I also hear the echo of a divine departure, guides the self in one irreversible direction. The trace, the path of God, is a one-way street, in fact, a double detour from oneself to the other. Any turning back to myself returns me home (chez moi) by another path, the path of consciousness, where neither my responsibility for the other nor the absence of God may be discerned. In preventing a return to oneself, divine absence serves as the condition for my irreversible and irreducible exposure to the approach of the other. God exposes me to the other, by rupturing the reflexive circuit of transcendental consciousness in me: "the fission of the transcendental subject" (Levinas [1993] 2000). The absence of God does not mean that my relation to God is devoid of events, such as the disruption of transcendental consciousness. However, it is devoid of divine presence or being, and any conscious events that would present God qua Being. To borrow a titular phrase from fellow phenomenologist Jean-Luc Marion, for Levinas, God is a God without being (Marion 1991; Levinas 1998).

Levinas thus prepares the way for a rather stunning thesis: "The supreme presence of a face is inseparable from this supreme and irreversible absence which funds (fond) the eminence of visitation" (Levinas [1967] 1986). The absence of God donates its transcendent height and moral stature to the face. In Totality and Infinity, Levinas had already tethered God to the face, in the sense that no revelation of God, if there were one, could take place apart from our ethical relation to the Other. Levinas now takes a second and unprecedented step. The face is now tethered to God. The presence of the face cannot take place apart from the absence of God, for the supreme eminence of the face, which Levinas describes so well in Totality and Infinity, comes to it by way of God's own supreme transcendence. What is truly stunning is the priority of the divine-human relation to the inter-human relation.

It is God, in its departure and thus absence, who provides transcendence for the coming of the face! My responsibility for the face before me is given by my relation to an absent God. Levinas reiterates the priority of the divine trace over the neighbor's face in the closing paragraphs of the same essay. "A face is of itself a visitation and transcendence. But a face, wholly open, can at the same time be in itself because it is in the trace of illeity. Illeity is the origin of the alterity of being" (Levinas [1967] 1986). In its absolute detachment, God is the origin of the disruption of being, a literal de-ontology, on account of which the infinite moral significance of the human face cuts across the 
finite appearances and being of self and other and world. The divine relation (to self and other) gives transcendence to the human relation.

The divine-human relation thus enjoys a priority of givenness with respect to the inter-human, a position that Levinas carries into Otherwise than Being: "illeity in the beyond-being is the fact that its coming toward me is a departure which lets me accomplish a movement toward a neighbor" (Levinas [1974] 1998). While God functions as the origin of the face, its transcendence prevents it from functioning as a principle (arche) for consciousness. God can neither function as a principle of consciousness nor become subject to a principle of consciousness. Thus, ironically, though one can speak of God as the origins of the face. One cannot make the further claim that this relation proves-an activity of consciousness-the existence of God. The un-principled "an-archy" of the divine not only ensures its susceptibility to skepticism, it is precisely what disrupts the principled activity of consciousness that allows for the turning of the self to the other. As the divine draws near unto me and my neighbor, I am drawn near in ethical proximity to my neighbor. The latter approach can similarly be told from the side of the other. The face of the other summons me in my responsibility, because it stands in the trace of a wholly transcendent and good God. The humanism of the neighbor thus owes its moral austerity to its origins in God, who sets the transcendence of responsibility upon finite human lips. The parting approach of God (à-dieu) from experience and being is the funding gift of ethics, even before the slightest sense of responsibility and awareness of reality crosses the mind. Notwithstanding present evidence, the community of scholars engaging with Levinas' work has tended to resist or has failed to adequately clarify or explain the divine provenance of human responsibility.

\section{Is God Dispensable?}

Levinas scholarship displays the difficulty of distinguishing between the face and the divine, and the seemingly irresolvable ambiguities that follow from this divine-other confusion. Levinas himself insists that "God is not separable from the responsibility for the neighbor" (Levinas [1993] 2000). "The dimension of the divine opens forth from the human face ... God rises to his supreme and ultimate presence as correlative to the justice rendered unto men" (Levinas [1961] 1969). Adriaan Perperzak puts it this way: "Levinas tries to explain that the relation to the human Other and the relation to God coincide completely and without fail. The only way of having a relation with God ... is to respond to the interpellation of the human face, to be good" (Peperzak 2005). This exclusive and unfailing coincidence of the divine and the human has led many to question whether the relation to God is not ultimately redundant, or otherwise reducible to human relations.

Michael Morgan represents one significant voice in the reductive camp. Addressing Levinas' use of "religious or theological vocabulary", he concedes that one could well mistake the moral command of the face with the epiphanic trace of a divine being. Yet, it is Morgan's contention that "Levinas wants to steer us away from such a conclusion, and the term 'illeity' is part of his warning ... to avoid the belief that God is a being who authorizes through command the obligation to care for the suffering of others" (Morgan 2007). Illeity, Morgan argues, does not signify some being—a divine entity—but rather a moral quality: "the third person [is] something distant, separate, and always so. Not I or you, it is that ... 'that-ness' or 'he-ness' ... Illeity is the otherness of the other ... its ethical force, its obligating me to respond to it, its compellingness and gravitas" (Morgan 2007). Morgan assumes that person implies being, such that a personalist interpretation of illeity would require us to understand God as a being-a position that Levinas tirelessly works to overcome. However, the significance of Levinas' entire oeuvre is to emancipate the significance and life of persons from the impersonality of being. To say God is a person does not imply that God is a being, as Morgan suggests. If it is true that "I" as the first person precede my being and likewise "you" the second person, why would it not be the case for "God" the third person? After the ethical liberation of the first and the second persons in Totality and Infinity, Levinas increasingly directs more of his work to the liberation of the meaning and person of God from the neutrality of being, a task that cannot happen without first articulating a de-ontological sense of meaning and personal responsibility (Levinas [1993] 2000). 
The full purchase of Morgan's reductive position is on display, as he concludes that "[w]hen we speak of encountering God or of God revealing Himself to me, this is an expression of my desire to respond to the other person with kindness and generosity, my sense of being called by the other and being obligated to her" (Morgan 2007). On this account, philosopher Merold Westphal has gone as far as accusing Levinas of "redefinitional" atheism, for the way that he reduces and redefines divine transcendence as ethical transcendence (Westphal 2010; Westphal 1995). There is a Kantian flavor to Morgan's reading of Levinas, and perhaps that of Westphal, at least as it relates to the ethical hermeneutics that justify religious observance.

In Religion within the Boundaries of Mere Reason, Immanuel Kant develops a reductive hermeneutics for religious life. He concedes that humans may need religious representations, which exceed both the justifiable parameters of objective reality and the universal prescriptions of moral reasoning. Nevertheless, he permits the use of these religious representations-original sin, bible stories, and church worship - if they can be recognized as representations, which 1) lack empirical and rational standing, and 2) are redefined in accordance with the moral aims of reason (Kant 1998). In this Kantian vein, Morgan interprets Levinas' use of religious language as mythological representations of moral responsibility. The notion of the divine as person enlists theological mythology to convey the gravity of human responsibility, rather than the transcendent origins of responsibility in the divine. While this reductive hermeneutic appears to reflect Levinas' position on Jewish ritual practice and sacred exegesis, it does not extend to the constitutive signification of the trace and the divine names in his philosophical works. Rather, the trace and the divine names signify in a constitutive manner the divine origin that has ordained infinite human responsibility.

Other scholars, such as Tamra Wright, have argued that the divine relation is essentially redundant for ethics (Wright 1999). She readily stipulates that the obligation of responsibility, which one apprehends, allows a person to move toward the cry of the other as well as give witness to God from whom this command comes. But she questions whether the divine provenance of the command says anything more than what is already being said in my responsibility for the other. In other words, it is perhaps true that one may hear God in the call to conscience. Yet, since the voice of God says nothing more than the voice of conscience, one can readily and ably live out one's concern for the other without acknowledging or recognizing the divinity of the voice. Moreover, her critique could be taken a step further to argue that there are no admissible criteria to distinguish between responsibility before human beings and responsibility before God. Since what presents itself in the face is a sense of human responsibility, there is neither need nor warrant for a distinct appeal to God.

Wright accommodates Levinas' thought to a secular audience at the expense of one of his most provocative and prominent proposals: God as the transcendent and personal origin of human responsibility. That Levinas is not doing theology in his philosophical works is a defensible, though contested, interpretation of Levinas' intentions (Janicaud 2000). That one can take the further step and dispense with the divine or religious significance of ethics in favor of an ethics without the trace of God-the balance of Levinas' mature texts and philosophical arguments oppose this secular thesis.

The idea that God is a dispensable coincidence fits with the peripheral consideration of God in Totality and Infinity, where it is not altogether clear (perhaps even to Levinas!) how God comes to mind, except as an idea. The ethical cast of transcendence was first and foremost two-fold - the I and an ambiguously divinized human other-with the occasional mention of a distinct relation to God. However, as soon as Levinas begins to shed more light on the distinct signification of God as person, the scales clearly tip in favor of a divine trace that 1) remains irreducible to one's responsibility for the other and 2) serves as its indispensable origin. It is worth noting that the scholars who seek to dispense with the moral significance of God—as redundant, reducible, or even corrosive-share a loosely Kantian interpretation of Levinas. Had these scholars considered the distinct temporality of the neighbor and the divine, they would perhaps have been in a better position to discern the temporal priority of God's absent passing over the disruptive arrival of the other. 


\section{Crossing Times: The Temporal Recurrence of a Departing God}

The two-fold signification of human responsibility and the divine trace are entangled within the singular event of my encounter with the other. There is no way to separate the distinct threads of this god-self-other encounter into independent strands, as the signification of responsibility and the signification of the trace are inseparably dependent upon one another. The meaning I give for the other-'Here I am' - coincides with the giving of meaning to God-the transcendent passing of the Infinite. Accounting for the distinct temporal orientations of responsibility and the trace enables one however to distinguish these interdependent threads of meaning without falling into the deforming abstraction of separating them.

Levinas' writing on time introduces the disorienting notion of diachronous temporality, or diachrony. In its Greek etymology, diachrony signifies cutting across time, or crossing time. It is the crossing of distinct times, analogous to two lines of music playing together at distinct time signatures, or the interwoven sound of the fetal and maternal heartbeats, diachronously beating across one another. Diachrony names the way that the temporal signature of responsibility cuts across that of the divine trace, crossing one another in the singular event of my encounter with the neighbor. "The neighbor strikes me before striking me, as though I had heard before he spoke. This anachronism attests to a temporality different from that which scans consciousness" (Levinas [1974] 1998). To cut through this paradox, one must understand the encounter with the other as a singular event unfolding across two times. The event is the encounter of the self and the other, and in its diachrony, it cuts across the present of my finite offering to the other and the past of the Infinite that has left me to care for the other. As I freely give myself to serve my neighbor, I sense that I have already been given over to serve her before my initiative or awareness. My present generosity answers to a prior debt, the origins of which I cannot recall.

The awakening of my responsibility for the neighbor unfolds across these distinct yet interwoven times. Whereas my responsibility gives meaning to the encounter at present, the trace of the divine commanding me gives meaning to the past that has prepared the way for the present. The events and moments of this ethical present do not flow into the past, as if time coursed across a synchronous one-dimensional plane with temporal events moving from the future through the present into the past. Diachronous time unfolds in the recurrence of the past as it cuts across the recurrence of the present. In short, the recurrence of my present responsibility cuts across the recurrence of the divine passing, the latter of which has always already come first to open and sustain the infinity of the path I tread toward my neighbor.

Responsibility unfolds across this distinctly ethical temporality of the present as the time for responding and caring for the other. The "Here I am" expresses a recurring temporal obsession for the welfare of the person in front of me. The obsession iterates the present moment-the recurrence of the now-as time for the other. Here I am, now! The other becomes more present to me than I am to myself, as the present moment no longer affords time for self-reflection or conscientious circumspection of the world. In this respect, the present no longer functions as the privileged time for empirical apprehension, representation, or presence. In my responsibility for her, my neighbor becomes more of my present than her empirical and finite presence could ever make sense of or justify. One faces one's responsibility for the other in the goodness of the present: irrespective of empirical actualities; without possibility of future delay or anticipation; and independent of shared history or novelty of acquaintance. The goodness of the present yields a time that is discontinuous and undetermined by our ordinary experience and empirical measure of the past, present, and future-hence, its diachrony. Diachrony cuts across the present moment of responsibility into a similarly discontinuous past, through which the irrecoverable origin of responsibility may be traced to God.

By way of the trace, I recognize that my responsibility gives voice to the recurring echo of an event that has already taken place in me. The "Here I am" is the echo of an ever prior yet similarly recurring event. This prior event is the passing of God, which has always already taken place again and again. The trace signifies this divine passing through the polynomic improvisation of divine names, not least 
of which is Adieu. In the Adieu, one signifies that God has come and gone. God has passed by me, though never before me. This means that I can neither recall nor remember within consciousness the event whereby God comes to pass, for it always takes place in what is for me an absolute past. As we have seen, the trace is the signification of my relation to this absolute past, whence God comes to pass. In the wake of this divine passing, God leaves me with the moral trace of this divine event. It is a trace, a path, that directs me toward the face of the other, not toward God. By way of this passing, an absent God leaves me responsible for the ones who will pass before me: the others who are left behind. Responsibility thus has its origins in the absolute past, where God passes by, leaving me with a divine trace or path toward the other.

By way of temporal analysis, one returns ever more clearly to the three-fold cast of transcendence: my responsibility for the other comes to me from God, who has always already passed me by. It is in virtue of this divine avenue of responsibility that ethics deserves the name of religion: "the trace of a relationship with illeity ... ordering me to responsibility. This relationship is religion, exceeding the psychology of faith and of the loss of faith" (Levinas [1974] 1998). It is religion that exceeds the religious psychology of ressentiment, which channels the hostility of the weak into the concept of a God who will avenge good and evil with consolations and punishments (Kosky 2001). The God of the "great punishment machine" is born of hostility and dies in nihilistic disillusion (Nietzsche 1968). In place of a compensatory divine, Levinas transforms God into the origin of a divine trace-path-for generous, meaningful, and sacrificial encounters among neighbors. In moving from vengeance to fraternity, from consolation and punishment to sacrificial generosity, it becomes possible to hear the ever-recurring echo of the personal yet absent origin of the God of the Good. The absent God of infinite responsibility gives meaning to "a relation that survives the 'death of God"" (Levinas [1974] 1998).

\section{In the End: Have We Been Fooled?}

"Everyone will readily agree that it is of the highest importance to know whether we are not duped by morality" (Levinas [1961] 1969). The opening line of Totality and Infinity opens Levinas' extraordinary critique against the primacy of the universal over the individual, against rational knowledge over moral desire, against the finite over the infinite. Have we been fooled by the pretense that a universal understanding of the finite goods of humanity suffices, that rational knowledge is enough to provoke and sustain the living out of the common good for the sake of thriving human communities? Such an inquiry calls into question the rational foundation of some of the great liberal traditions of the 19th and 20th century-the cultural propagation of humanist and emancipatory values within liberal democracies, human rights advocacy of political and social stripes, increased awareness and concern for suffering around the world, institutional integrity and accountability-traditions that I and other liberal heirs of the Enlightenment have every impulse to cultivate and no desire to reject. Yet, the passionate resurgence of nationalist xenophobia in Western liberal democracies, quite literally the fear of the other, offers more than sufficient reason to pause and ask once more whether we have not been duped by our confidence in the universal and strictly human origins of morality, at least as to the adequacy of these laudable traditions. Has universal knowledge of the common good-in thought and institutional practice-not shown itself incapable of transforming or humanely restraining the seemingly primal course of self-conscious expansion and coercive dominance of self over others-the will to power?

In light of the conceptual and empirical shortfalls of secular humanism over the last two centuries, Levinas' work counsels that we ground concern for human welfare on the basis of something more primal than universal reason. Before and beyond the abstract universality of reason, there is infinite responsibility for the unique one who stands before me-a radical and personal singularity of meaning in the face of the neighbor. It is infinite responsibility that will safeguard the integrity and welfare of the individual in the world. Yet, how can my encounter with another human being summon a sense of infinite responsibility? The absurd, if not monstrous, excess of infinite responsibility warrants that Levinas' own proposal be subjected to the suspicion of dupery. Have we been fooled by an ethics 
of infinite responsibility? In certain respects, the introduction of the divine as third person may be regarded as the fruit of Levinas himself asking this very question of the work he had just completed in Totality and Infinity. Is it not utterly foolish to think that another human being can of itself provoke the infinite weight of transcendence and responsibility that one feels in its presence? Levinas' mature ethics corrects this "foolishness" by establishing the possibility of an infinite human ethic on the ever prior and transcendent giving of responsibility by the divine. The one whom I never see-ille- "that one" is the true Infinite and Absolute that leaves its divine trace on me as bearer of human responsibility. In this way, Levinas confirms and amplifies what Jacques Derrida had already suspected of Totality and Infinity - the profound insinuation of the divine in the face of the Other (Derrida 1978). The increasing appeal to the divine within Levinas' mature ethics is an attempt to describe the transcendent origin that gives infinite human responsibility. It is a humanism founded on the infinite goodness of God.

While one may be persuaded of the rational need for a transcendent and divine origin of human responsibility, it remains to be seen whether we have not been fooled by insisting on the radical absence of the divine: "transcendent to the point of absence" (Levinas [1993] 2000). While the moral trace of an absent God provides meaningful access to the divine, it does so in the form of an unbearable paradox. The divine trace leads ever away from God, who can never be seen or encountered face-to-face. There can be no experience of God in the trace that this Ancient One leaves behind. The trace of God thus signals a void: the continuous departure of God, for which one will always arrive far too late. Though the Infinite awakens me to my responsibility, it has always already departed and thus cannot be found within it. It is as if I am a child relegated to saying adios, adieu to a God, a personal origin, in fact the origin of persons, whom I have never met and will never meet. After a while, it becomes difficult to discern the difference between absence and abandonment, between an ephemeral trace and Quixotic dreams, between the still soft voice of God and the indifferent rustling of being (Levinas [1974] 1998). Perhaps, my neighbor is the only surviving face of God after the "one single catastrophe which keeps piling wreckage upon wreckage" of human suffering and genocide at the feet of the angel of history (Benjamin 1968). Yet, it leaves one wondering, whether humans can responsibly bear the catastrophe of our times and bear the absence of God in a way that gives meaningful witness to the divine.

Funding: This research received no external funding.

Conflicts of Interest: The author declares no conflict of interest.

\section{References}

Benjamin, Walter. 1968. Theses on the Philosophy of History. In Illuminations: Essays and Reflections. Translated by Harry Zohn. New York: Schocken Books.

Derrida, Jacques. 1978. Violence and Metaphysics. In Writing and Difference. Translated by Alan Bass. Chicago: University of Chicago Press.

Descartes, René. 1984. Meditations on First Philosophy. In The Philosophical Writings of Descartes: Vol. 2. Translated by John Cottingham, Robert Stoothoff, and Dugald Murdoch. Cambridge: Cambridge University Press.

Franks, Paul. 2010. Should Jews and Christians Fear the Gifts of the Greeks? Reflections on Levinas, Translation, and Atheistic Theology. In The Exorbitant: Emmanuel Levinas between Jews and Christians. Edited by Kevin Hart and Michael A. Signer. New York: Fordham University Press, pp. 211-15.

Gschwandtner, Christina M. 2012. Postmodern Apologetics? Arguments for God in Contemporary Philosophy. New York: Fordham University Press.

Heidegger, Martin. 1969. Identity and Difference. Translated by Joan Stambaugh. New York: Harper \& Row.

Janicaud, Dominique. 2000. Phenomenology and the "Theological Turn": The French Debate. Translated by Bernard G. Prusak. New York: Fordham University Press.

Kant, Immanuel. 1998. Religion within the Boundaries of Mere Reason. Edited by Allen Wood and George di Giovanni. Cambridge: Cambridge University Press.

Kosky, Jeffrey L. 2001. Levinas and the Philosophy of Religion. Bloomington: Indiana University Press.

Levinas, Emmanuel. 1969. Totality and Infinity: Essay on Exteriority. Translated by Alphonso Lingis. Pittsburgh: Duquesne University Press, Totalité et infini. Den Haag: Martinus Nijhoff, 1961. 
Levinas, Emmanuel. 1986. The Trace of the Other. In Deconstsruction in Context. Translated by Alphonso Lingis. Chicago: University of Chicago Press, pp. 345-59, La trace de l'autre. In En découvrant l'existence avec Husserl et Heidegger. Paris: Vrin, 1967, pp. 261-82.

Levinas, Emmanuel. 1987. Time and the Other. Translated by Richard A. Cohen. Pittsburgh: Duquesne University Press.

Levinas, Emmanuel. 1996. God and Philosophy. In Emmanuel Levinas: Basic Philosophical Writings. Bloomington: Indiana University Press, Dieu et la philosophie. In De Dieu qui vient à l'idée. Paris: Vrin, 1998.

Levinas, Emmanuel. 1998. Otherwise than Being or Beyond Essence. Translated by Alphonso Lingis. Pittsburgh: Duquesne University Press, Autrement qu'être ou au-dèla de l'essence. Den Haag: Martinus Nijhoff, 1974.

Levinas, Emmanuel. 1998. Philosophy, Justice, and Love. In Entre Nous: Thinking-of-the-Other. Translated by Barbara Harshav, and Michael B. Smith. New York: Columbia University Press.

Levinas, Emmanuel. 1998. The Other, Utopia, and Justice. In Entre nous: On Thinking-of-the-Other. Translated by Barbara Harshav, and Michael B. Smith. New York: Columbia University Press, L'autre, utopie, et justice. In Entre nous: Essais sur le penser-à-l'autre. Paris: Éditions Grasset \& Fasquelle, 1991.

Levinas, Emmanuel. 2000. God, Death, and Time. Translated by Bettina Bergo. Stanford: Stanford University Press, Dieu, la mort et le temps. Paris: Éditions Grasset \& Fasquelle, 1993.

Levinas, Emmanuel. 2001. Énigme et phénomène. In En découvrant l'existence avec Husserl et Heidegger. Paris: Vrin. Llewelyn, John. 1995. Emmanuel Levinas: The Geneology of Ethics. London: Routledge.

Maloney, Philip J. 2014. Dreaming Otherwise than Icarus: Heidegger, Levinas, and the Secularization of Transcendence. In Between Levinas and Heidegger. Edited by John E. Drabinski and Eric S. Nelson. Albanay: SUNY Press, pp. 31-50.

Marion, Jean-Luc. 1991. God without Being. Chicago: University of Chicago Press.

Morgan, Michael. 2007. Discovering Levinas. Cambridge: Cambridge University Press.

Nietzsche, Friedrich. 1968. The Will to Power. Edited by Walter Kaufmann. New York: Vintage Books.

Peperzak, Adriaan. 2005. To the Other: An Introduction to the Philosophy of Emmanuel Levinas. West Lafayette: Purdue University Press.

Taminiaux, Jacques. 1997. The early Levinas' reply to Heidegger's fundamental ontology. Philosophy E Social Criticism 23: 29-49.

Simmons, J. Aaron. 2010. Continuing to Look for God in France: On the Relationship between Phenomenology and Theology. In Words of Life. Edited by Bruce Ellis Benson and Norman Wirzba. New York: Fordham University Press, pp. 15-29.

Westphal, Merold. 1995. Levinas' Teleological Suspension of the Religious. In Ethics as First Philosophy: The Significance of Emmanuel Levinas for Philosophy, Literature, and Religion. Edited by Adriaan T. Peperzak. New York: Routledg.

Westphal, Merold. 2001. Overcoming Onto-theology: Toward a Postmodern Christian Faith. New York: Fordham University Press.

Westphal, Merold. 2010. Thinking aboug God and God-Talk with Levinas. In The Exorbitant: Emmanuel Levinas beteen Jews and Christians. Edited by Kevin Hart and Michael A. Signer. New York: Fordham University Press, pp. 216-28.

Wright, Tamra. 1999. The Twilight of Jewish Philosophy: Emmanuel Levinas' Ethical Hermeneutics. Amsterdam: Harwood Academic Publishers.

Zimmerman, Nigel. 2013. Levinas and Theology. New York: Bloomsbury T\&T Clark.

(C) 2019 by the author. Licensee MDPI, Basel, Switzerland. This article is an open access article distributed under the terms and conditions of the Creative Commons Attribution (CC BY) license (http://creativecommons.org/licenses/by/4.0/). 